\title{
Design and Synthesis of Immunoconjugates and Development of an Indirect ELISA for Rapid Detection of 3, 5-Dinitrosalicyclic Acid Hydrazide
}

\author{
Yu-Dong Shen ${ }^{1}$, Shi-Wei Zhang ${ }^{1}$, Hong-Tao Lei ${ }^{1}$, Hong Wang ${ }^{1}$, Zhi-Li Xiao ${ }^{1}$, \\ Yue-Ming Jiang ${ }^{2, *}$ and Yuan-Ming Sun ${ }^{1, *}$
}

1 College of Food Science, South China Agricultural University, Guangzhou 510642, P. R. China; E-mails: sydscau@yahoo.cn (Y-D.S),zsw_8506@163.com (S-W.Z), hongtao@scau.edu.cn (H-T. W); gzwhongd@163.com (H.W.); scauxzl@scau.edu.cn (Z-L.X)

2 South China Botanical Garden, Chinese Academy of Sciences, Guangzhou 510650, P. R. China

* Authors to whom correspondence should be addressed; E-mails: ymsun@scau.edu.cn (Y-M. S) or ymjiang@scib.ac.cn (Y-M. J).

Received: 22 August 2008; in revised form: 14 September 2008 / Accepted: 16 September 2008 / Published: 23 September 2008

\begin{abstract}
In this study novel immunoconjugates were designed, synthesized and then used to develop a rapid, specific and sensitive indirect ELISA method to directly detect residues of 3,5-dinitrosalicyclic acid hydrazide (DNSH), a toxic metabolite of nifursol present in chicken tissues. The hapten DNSHA was first designed and used to covalently couple to BSA to form an immunogen which was immunized to rabbits to produce a polyclonal antibody against DNSH. Furthermore, a novel 3,5-dinitrosalicylic acidovalbumin (DNSA-OVA) immunoconjugate structurally different from DNSHA-OVA was designed and used as a "substructural coating antigen" to improve the sensitivity of an indirect ELISA analysis for a direct DNSH detection. Based on the "substructural coating antigen" concept, an optimized indirect ELISA method was established that exhibited good specificity and high sensitivity for detecting DNSH, with a cross-reactivity of less than $0.1 \%$ (excluding the parent compound nifursol), $\mathrm{IC}_{50}$ of $0.217 \mathrm{nmol} / \mathrm{mL}$ and detection limit of $0.018 \mathrm{nmol} / \mathrm{mL}$. Finally, a simple and efficient analysis of DNSH samples in chicken tissues showed that the average recovery rate of the indirect ELISA analysis was $82.3 \%$,
\end{abstract}


with the average coefficient of variation $15.9 \%$. Thus, the developed indirect ELISA method exhibited the potential for a rapid detection of DNSH residues in tissue.

Keywords: Nifursol, DNSH, Hapten design, Indirect ELISA

\section{Introduction}

Nifursol is a member of the nitrofuran antibiotics family (Figure 1), which is used extensively as a feed additive for the prevention of histomoniasis. Due to the potentially harmful effects of nifursol on human health, its use in food-producing animals has been banned in the European Union since 2002 [1]. As nifursol was rapidly metabolized to form the metabolic marker 3,5-dinitrosalicyclic acid hydrazide (DNSH, Figure 1) which can persist for a long time in vivo, several laboratories have focused on development of DNSH detection methods [2-4]. At present, the detection of DNSH is mainly at the $\mu \mathrm{g} / \mathrm{kg}$ level by HPLC-MS methods, which are based on the analysis of the DNSH derivative 2-hydroxy-3,5-dinitro- $N^{\prime}$-(2-nitrobenzylidene)benzohydrazide (NPDNSH, Figure 1) [2-4]. Disadvantageously, these analytical methods not only require a time-consuming and troublesome derivatization step and expensive apparatus but also have low sample throughput.

Immunoassay is an efficient screening technique for monitoring of illegal and harmful chemicals in food and the environment, which exhibits the great advantages of speed and high sample throughput [5]. To the best of our knowledge, there have been no reports on the development of a specific antibody to DNSH and an immunoassay for a direct detection of DNSH. This study reports for the first tme the synthesis of immunoconjugates for DNSH, the preparation of a polyclonal antibody against DNSH and the development of an indirect competitive enzyme-linked immunosorbent assay (indirect ELISA) for rapidly analyzing DNSH residues present in chicken tissue. At the same time, this study developed a "substructural coating hapten" strategy to improve the precision of indirect ELISA for detecting DNSH.

Figure 1. The structures of nifursol, DNSH, NPDNSH, DNSA and DNSHA [2-4].<smiles>O=C(N/N=C/c1ccc([N+](=O)[O-])o1)c1cc([N+](=O)[O-])cc([N+](=O)[O-])c1O</smiles>

Nifursol<smiles>O=C(N/N=C/c1ccccc1[N+](=O)[O-])c1cc([N+](=O)[O-])cc([N+](=O)[O-])c1O</smiles>

NPDNSH<smiles>NNC(=O)c1cc([N+](=O)[O-])cc([N+](=O)[O-])c1O</smiles>

DNSH<smiles>O=C(O)C=NNC(=O)c1cc([N+](=O)[O-])cc([N+](=O)[O-])c1O</smiles>

DNSHA<smiles>O=C(O)c1cc([N+](=O)[O-])cc([N+](=O)[O-])c1O</smiles>

DNSA 


\section{Results and Discussion}

\section{Immunogen design and synthesis}

The structural design of the hapten is an important step in the development of immunoassays for small organic analytes. As the structure of the hapten used to form an immunogen can remarkably affect the sensitivity and specificity of the antibody, the hapten should be a near perfect mimic of the structure of the target analyte [6-8]. On the other hand, as organic molecules of less than 1,000 Da possess no antigenicity, they must be covalently conjugated to a carrier protein by introducing a linker with an active terminal group on its organic molecular structure to form a complete antigen to smoothly elicit a specific immune response. Furthermore, the arm used to couple to a carrier protein was another key role in hapten design, which should not elicit antibody recognition in itself [8]. Generally, an appropriate linear hydrocarbon handle is necessary. Our previous studies showed that a short unsaturated linear chain which was attached to target molecule can remarkably improve the capability to evoke a specific immune response [9]. In this study, a short unsaturated arm based on glyoxalic acid was directly introduced into the target analyte to form a DNSHA hapten which was covalently linked to the carrier protein bovine serum albumin (BSA) to produce a DNSHA-BSA immunogen (Figure 2).

Figure 2. Synthesis of immunogen DNSHA-BSA [10-13].<smiles>O=C(O)c1cc([N+](=O)[O-])cc([N+](=O)[O-])c1O</smiles>

DNSA<smiles>COC(=O)c1cc([N+](=O)[O-])cc([N+](=O)[O-])c1O</smiles>

MDNSA

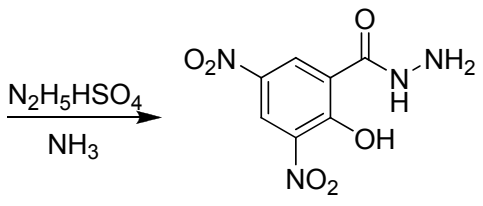

DNSH

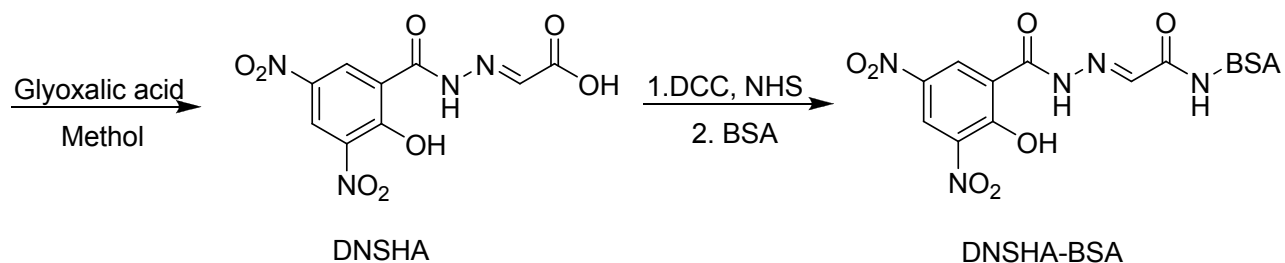

NMR and MS analyses, as indicated by in the Experimental, confirmed that the DNSHA hapten was prepared. The DNSHA-BSA immunogen was synthesized by the active ester method [13]. UV spectra showed qualitative differences between the carrier protein and conjugate in the maximum absorbance of hapten, which suggested the presence of DNSHA-BSA. Furthermore, the ratio of DNSHA coupling to BSA was determined to be 21:1 by the TNBS method [14].

Design, synthesis and choice of coating antigens

The structure of the hapten used to form a coating antigen has a direct effect on the immunoassay [15]. Generally, immunohapten and target analyte have a similar structure and their affinities for an 
antibody are almost identical. Thus, homologous coating using an immuno-hapten-OVA conjugate as a coating antigen usually results in a similar or weaker recognition of the antibody towards the target analyte. The "substructural coating hapten", a major structure of which was one of the fragments of target analyte structure, can improve remarkably the competitive recognition sensitivity of antibody to a target analyte, which could result from less interaction regions or points of the "substructural coating hapten" with the pocket area of the antibody than those of the analyte. Based on this concept, DNSA was designed as a "substructural coating hapten" for detecting DNSH by indirect ELISA. In addition, in order to prove the validity of the "substructural coating hapten" concept, standard curves of DNSH were established under optimum conditions using DNSA-OVA as coating antigen and DNSHA-OVA as a control, respectively. As we had expected, the result shows that the $\mathrm{IC}_{50}$ and detection limit of the indirect ELISA with DNSA-OVA as coating antigen were much better than those of the indirect ELISA with DNSHA-OVA (Table 1), which suggested that the "substructural coating hapten" strategy for indirect ELISA improvement was rational and efficient.

Figure 3. UV spectra of BSA, OVA, DNSHA-BSA, DNSHA-OVA and DNSHA.

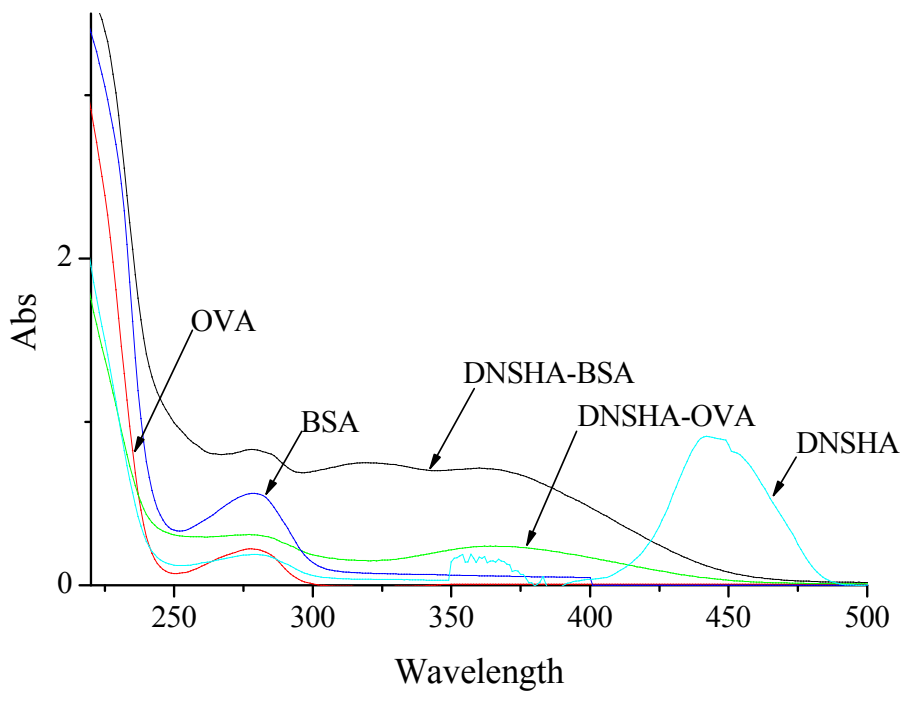

Figure 4. UV spectra of OVA, DNSA-OVA and DNSA.

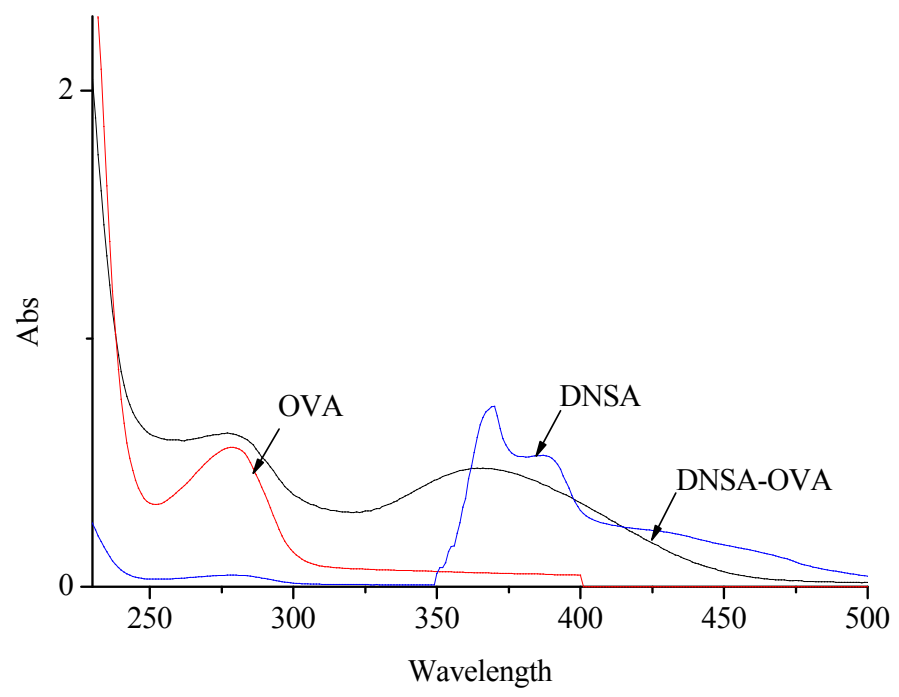


Coating antigens were also synthesized by the active ester method with OVA instead of BSA [13]. UV spectra show qualitative differences between OVA and conjugates (DNSHA-OVA or DNSA-OVA) in the maximum absorbance of corresponding haptens (DNSHA or DNSA), as shown in Figures 3 and 4, which suggested the presence of DNSHA-OVA and DNSA-OVA. The molar ratio of DNSHA and DNSA coupling to OVA were determined to be 11:1 by the TNBS method [14].

Table 1. Indirect ELISA evaluation for DNSH with different coating antigens.

\begin{tabular}{cccc}
\hline Immunogen & Coating antigen & $\mathbf{I C}_{\mathbf{5 0}}(\mathbf{n m o l} / \mathbf{m L})$ & Detection limit $(\mathbf{n m o l} / \mathbf{m L})$ \\
\hline \multirow{2}{*}{ DNSHA-BSA } & DNSHA-OVA & 10.328 & 0.892 \\
& DNSA-OVA & 0.217 & 0.018 \\
\hline
\end{tabular}

Table 2. Cross-reactivity of the antibody with various chemicals.

\begin{tabular}{ccc}
\hline Competitor & IC $_{\mathbf{5 0}}(\mathbf{n m o l} / \mathbf{m L})$ & Cross-reactivity (\%) \\
\hline Nifursol & 0.217 & 100 \\
3-5-Dinitrosalicyclic acid hydrazide (DNSH) & 0.069 & 314.5 \\
5-Methylamorfolino-3-amino-2-oxazolidone (AMOZ) & $>1000$ & $<0.1$ \\
1-Aminohydantoin (AHD) & $>1000$ & $<0.1$ \\
Semicarbazide (SEM) & $>1000$ & $<0.1$ \\
Ciprofloxacin & $>1000$ & $<0.1$ \\
Enrofloxacin & $>1000$ & $<0.1$ \\
Clenbuterol & $>1000$ & $<0.1$ \\
Salbutamol & $>1000$ & $<0.1$ \\
Ractopamine & $>1000$ & $<0.1$ \\
Malachite green & $>1000$ & $<0.1$ \\
\hline
\end{tabular}

Evaluations of antibody specificity and indirect ELISA

A DNSH standard curve (Figure 5) was prepared using DNSA-OVA as coating antigen, with a coating concentration of $1000 \mathrm{ng} / \mathrm{mL}$, antibody dilution of 1:2000, competitive time of $1 \mathrm{~h}$, sheep antirabbit $\mathrm{IgG}$ dilution of $1: 10000$ and reaction time of $20 \mathrm{~min}$. The $\mathrm{IC}_{50}$ (concentration causing $50 \%$ inhibition of binding) was $0.217 \mathrm{nmol} / \mathrm{mL}$. The limit of detection (the concentration causing $90 \%$ 
inhibition of binding) was $0.018 \mathrm{nmol} / \mathrm{mL}$. The linear detection range (the concentration correspondong to $20 \%$ to $80 \%$ inhibition of binding) was 0.046 to $1.029 \mathrm{nmol} / \mathrm{mL}$. In addition, under the optimized indirect ELISA conditions, the specificity of the antibody was estimated using DNSAOVA as coating antigen and ten frequently-used chemicals as competitors (Table 2). The results show that the cross-reactivity rates for the above-mentioned ten competitors, excluding nifursol (the parent compound of the analyte), were all less than $0.1 \%$, which suggested the antibody possessed a high specificity for detection of DNSH and the parent compound nifursol (Table 2). However, nifursol could be quite rapidly metabolized into DNSH in vivo, so its high cross-reactivity rate didn't affect the indirect ELISA's application to DNSH in real samples. The study indicated that the indirect ELISA method could be practical for development of commercial ELISA kits for monitoring DNSH residues in chicken tissues.

Figure 5. Standard curve of indirect ELISA for DNSH ( $\mathrm{n}=3)$.

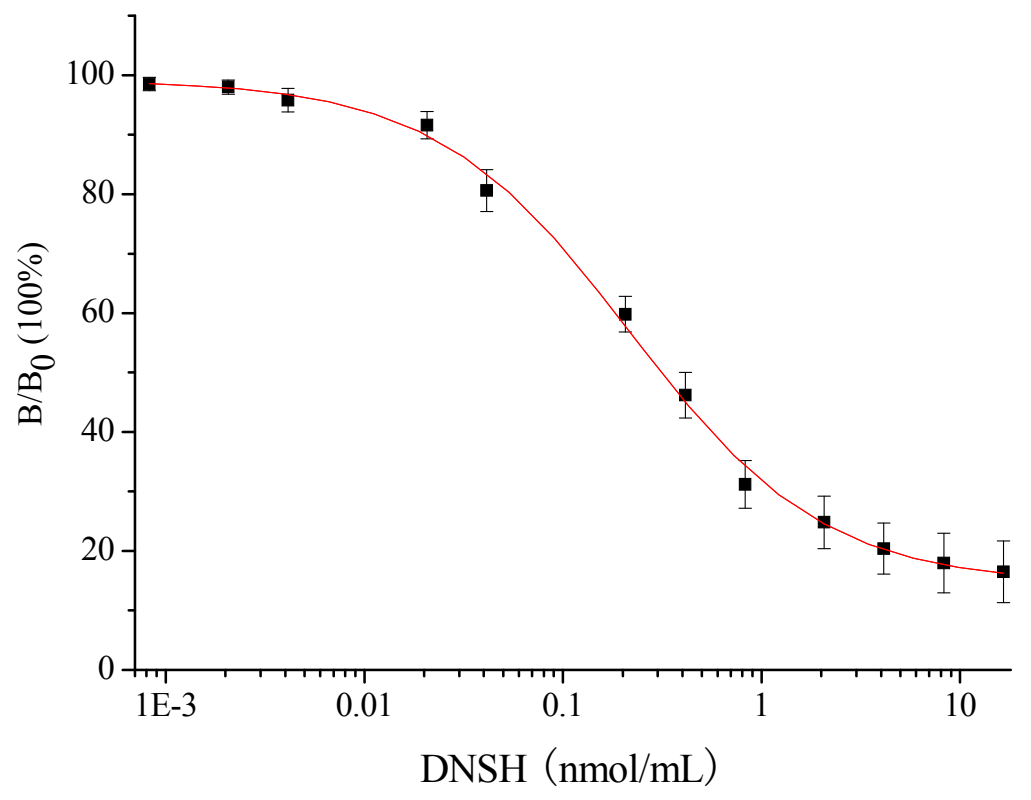

Sample analysis

Pretreatment of samples. Generally, the DNSH present is bonded with animal tissues in vivo and it appears in a free form by acid hydrolysis [4]. The chicken tissues mixed with DNSH were extracted with water. Ether was used to degrease the samples because of insolubility of DNSH in ether, while methanol was used to remove tissue proteins from aqueous solution with DNSH. A pretreatment period of less than 50 min was used in this study.

Analysis of samples. The indirect ELISA method was used to detect DNSH present in chicken samples. The analysis results are summarized in Table 3 . All coefficients of variation were below $18.4 \%$ and the average recovery was $82.3 \%$, which suggested that good precision was obtained in this study. 
Table 3. Analysis of DNSH present in chicken tissues by indirect ELISA $(n=3)$.

\begin{tabular}{cccc}
\hline $\begin{array}{c}\text { Fortification } \\
\text { Level (nmol/mL) }\end{array}$ & $\begin{array}{c}\text { Mean } \pm \text { S.D. } \\
(\mathbf{n m o l} / \mathbf{m L})\end{array}$ & $\begin{array}{c}\text { Recovery } \\
\mathbf{( \% )}\end{array}$ & $\begin{array}{c}\text { CV } \\
\mathbf{( \% )}\end{array}$ \\
\hline 0.10 & $0.076 \pm 0.014$ & 76.0 & 18.4 \\
0.20 & $0.17 \pm 0.03$ & 85.0 & 17.6 \\
0.80 & $0.69 \pm 0.09$ & 86.2 & 13.0 \\
2.00 & $1.64 \pm 0.24$ & 82.0 & 14.6 \\
Means & & 82.3 & 15.9 \\
\hline
\end{tabular}

\section{Conclusions}

Based on the concept of "substructural coating antigen", an indirect ELISA for direct DNSH detection, with an $\mathrm{IC}_{50}$ value of $0.217 \mathrm{nmol} / \mathrm{mL}$ and a limit of detection of $0.018 \mathrm{nmol} / \mathrm{mL}$, was developed in this study. The indirect ELISA was applied for DNSH determination in chicken samples, with a pretreatment and detection period of less than $2.5 \mathrm{~h}$. Coefficients of variation were about $18.4 \%$ and the mean recoveries were $82.3 \%$. Thus, this indirect ELISA with high sensitivity and good stability could potentially be used to develop commercial ELISA kits for a sensitive and rapid detection of DNSH residues.

\section{Experimental}

\section{Chemicals and reagents}

3,5-Dinitrosalicylic acid (DNSA), $N$-hydroxysuccinimide (NHS), dicyclohexylcarbodiimide (DCC), 3,3',5,5'-tetramethylbenzidine (TMB), bovine serum albumin (BSA) and ovalbumin (OVA) were purchased from Sigma Chemical Company. N,N-Dimethylformamide (DMF), Tween-20 and methanol were obtained from Damao Co. Ltd (Tian Jin, P.R. China). Thin-layer chromatography (TLC) was done using $0.25-\mathrm{mm}$ precoated silica gel GF254 on aluminum sheets purchased from Qingdao Haiyang Chemical Co. Ltd. (Qingdao, P.R. China). New Zealand white rabbits were supplied by the Guangdong Medical Experimental Animal Centre. Enzyme immunoassay grade horseradish peroxidase (HRP), peroxidase-labeled goat antirabbit IgG were obtained from Wuhan Boster Biotech Co. The other chemicals were purchased from Alfa Corporation. Polystyrene ELISA plates were obtained from Guangzhou Jiete Biotech Co. and then treated with a Multiskan MK2 microplate washer (Thermo Labsystems). Absorbance in ELISA analysis was recorded with a Multiskan MK3 microplate reader (Thermo Labsystems). HPLC-MS analyses were performed using an Agilent HP1100 series (Agilent, Palo Alto, CA). Ultraviolet-visible (UV) spectra were obtained on a UV-160A Shimadzu spectrophotometer (Kyoto, Japan) and ${ }^{1} \mathrm{H}-\mathrm{NMR}$ spectra were recorded using a DRX-600 NMR spectrometer (Bruker, Germany-Switzerland). The buffers used in this study were as follows: 0.1 $\mathrm{mol} / \mathrm{L}$ phosphate buffer saline (PBS) containing $2 \mathrm{~mol} / \mathrm{L} \mathrm{NaOH}$ for sample neutralization, $50 \mathrm{mmol} / \mathrm{L}$ carbonate buffer ( $\mathrm{pH}$ 9.6) for coating, $10 \mathrm{mmol} / \mathrm{L}$ phosphate buffer saline (PBS) with $0.1 \%$ Tween-20 for washing, $0.1 \mathrm{~mol} / \mathrm{L}$ sodium acetate $(\mathrm{pH} 5.5)$ for substrate buffer and $2 \mathrm{~mol} / \mathrm{L} \mathrm{H}_{2} \mathrm{SO}_{4}$ as the stopping 
reagent. In addition, the substrate solution for horseradish peroxidase was prepared by addition of 10 $\mathrm{mL}$ of above-mentioned PBS substrate buffer and $150 \mu \mathrm{L}$ of $1 \%(\mathrm{w} / \mathrm{v}) \mathrm{TMB}$ solution into DMF and $2.5 \mu \mathrm{L}$ of $6 \%(\mathrm{w} / \mathrm{v}) \mathrm{H}_{2} \mathrm{O}_{2}$.

Synthesis of methyl 3,5-dinitrosalicylate (MDNSA)

DNSA (2.28 g) was dissolved in methanol $(50 \mathrm{~mL})$, and the solution was heated under reflux with stirring for $24 \mathrm{~h}$ after the addition of $98 \% \mathrm{H}_{2} \mathrm{SO}_{4}(0.5 \mathrm{~mL})$. About half of the solution was removed under vacuum before $\mathrm{Na}_{2} \mathrm{CO}_{3}$ was added until no gas bubbles were observed. The obtained residue was dissolved in water $(100 \mathrm{~mL})$ and MDNSH $(2.1 \mathrm{~g})$ was separated by filtration and washed 3 times with water. APCI-MS analysis (negative) $\mathrm{m} / z 241[\mathrm{M}-\mathrm{H}]^{-} ;{ }^{1} \mathrm{H}-\mathrm{NMR}\left(600 \mathrm{MHz}, \mathrm{CDCl}_{3}\right.$ and TMS): $\delta$ $9.03(\mathrm{~d}, J=3.0 \mathrm{~Hz}, 1 \mathrm{H}, \mathrm{ArH}), 9.01(\mathrm{~d}, J=3.0 \mathrm{~Hz}, 1 \mathrm{H}, \mathrm{ArH})$ and $4.12\left(\mathrm{~s}, 3 \mathrm{H}, \mathrm{CH}_{3}\right)$.

\section{Synthesis of 3,5-dinitrosalicyclic acid hydrazide (DNSH)}

MDNSA ( $1 \mathrm{~g})$ was reacted with hydrazine sulphate $(0.8 \mathrm{~g})$ and then suspended in $30 \%$ ammonia $(200 \mathrm{~mL})$. The mixture was allowed to stand for $24 \mathrm{~h}$ at $60{ }^{\circ} \mathrm{C}$ and then filtered. The filtered residue was washed with ethanol and then recrystallized from methanol to give DNSH $(0.7 \mathrm{~g}, 70 \%$ yield $)$ as yellow crystals. APCI-MS analysis (negative) $m / z$ was $241[\mathrm{M}-\mathrm{H}]^{-}$while ${ }^{1} \mathrm{H}-\mathrm{NMR}\left(600 \mathrm{MHz}, d_{6^{-}}\right.$ DMSO and TMS): $\delta 8.92(\mathrm{~d}, J=3.0 \mathrm{~Hz}, 1 \mathrm{H}, \mathrm{ArH})$ and $8.72(\mathrm{~d}, J=3.0 \mathrm{~Hz}, 1 \mathrm{H}, \mathrm{ArH})$.

Synthesis of 2-(2-(2-hydroxy-3,5-dinitrobenzoyl)hydrazono) acetic acid (DNSHA)

To a methanol solution $(10 \mathrm{~mL})$ containing glyoxalic acid $(0.11 \mathrm{~g})$, DNSH $(0.24 \mathrm{~g})$ was added. The mixture was allowed to stand for $3 \mathrm{~h}$ at about $25^{\circ} \mathrm{C}$ and then filtered. The filtered residue was washed three times with ethanol to give DNSHA $(0.21 \mathrm{~g}, 72 \%$ yield $)$ as a yellow powder. APCI-MS analysis (negative) $m / z 297[\mathrm{M}-\mathrm{H}]^{-} ;{ }^{1} \mathrm{H}-\mathrm{NMR}\left(600 \mathrm{MHz}, d_{6}\right.$-DMSO and TMS): $\delta 14.13$ (s, 1H, OH); 8.78 (d, $J=3.0 \mathrm{~Hz}, 1 \mathrm{H}, \mathrm{ArH}), 8.58(\mathrm{~d}, J=3.0 \mathrm{~Hz}, 1 \mathrm{H}, \mathrm{ArH}), 7.95(\mathrm{~s}, 1 \mathrm{H}, \mathrm{N}=\mathrm{CH})$ and $7.70(\mathrm{~s}, 1 \mathrm{H}, \mathrm{NH})$.

\section{Preparation of immunizing conjugates}

DNSHA (or DNSA) $(10 \mu \mathrm{mol})$, NHS ester $(10 \mu \mathrm{mol})$ and DCC $(10 \mu \mathrm{mol})$ were dissolved in DMF solution $(1000 \mu \mathrm{L})$. The mixture was gently stirred overnight at $4{ }^{\circ} \mathrm{C}$ and then centrifuged $(2,500 \mathrm{rpm}$ for $10 \mathrm{~min}$ ) to remove precipitated urea. The clear supernatant phase was collected and $900 \mu \mathrm{L}$ of the supernatant was added to BSA or OVA $(60 \mathrm{mg})$ in PBS $(\mathrm{pH} 7.4,9 \mathrm{~mL})$. The reaction mixtre was stirred overnight at $4{ }^{\circ} \mathrm{C}$ and then dialyzed against $0.9 \% \mathrm{NaCl}$ solution $(1,000 \mathrm{~mL})$ for 3 days at $4{ }^{\circ} \mathrm{C}$ with three changes per day to give the DNSHA-BSA, DNSHA-OVA and DNSA-OVA immunoconjugates. They were respectively diluted to $1 \mathrm{mg} / \mathrm{mL}$ with $0.9 \% \mathrm{NaCl}$ solution and then stored at $20^{\circ} \mathrm{C}$ until used. The ratios of DNSHA and DNSA to carrier proteins were determined by the TNBS method. 


\section{Preparation of polyclonal antibody to DNHS}

For booster immunizations, immunogen $(1 \mathrm{mg})$ was dissolved in $0.01 \mathrm{~mol} / \mathrm{L} \mathrm{PBS}(\mathrm{pH} 7.4,0.5 \mathrm{~mL})$ and emulsified with Freund's incomplete adjuvant $(0.5 \mathrm{~mL})$. The emulsion was then injected subcutaneously. The booster immunizations were repeated every three weeks. The New Zealand white rabbit was bled through ear vein one week after each injection. To obtain antiserum, blood samples were left to coagulate for $1 \mathrm{~h}$ at about $25^{\circ} \mathrm{C}$ and overnight at $4{ }^{\circ} \mathrm{C}$, followed by centrifugation for 10 min at 10,000 rpm. The clear supernatant phase was carefully collected. The polyclonal antibody was purified from antiserum by the ammonium sulfate precipitation method [16], then divided into aliquots and finally stored at $-20^{\circ} \mathrm{C}$ until used.

\section{Indirect ELISA procedure}

Standard DNSH and its structurally related compounds were diluted to various concentrations with PBS before the ELISA assay. The checkerboard procedure was used to optimize the coating antigen and the antibody concentrations. For the ELISA, each well of a microtitre plate was coated with 100 $\mu \mathrm{L}$ coating antigen (DNSA-OVA or DNSHA-OVA) at the optimal dilution and then incubated overnight at $4{ }^{\circ} \mathrm{C}$. The excess binding sites were blocked with $5 \%$ glycine for $3 \mathrm{~h}$ at $37^{\circ} \mathrm{C}$. After removal from the blocking solution, the optimal antibody dilution solution $(50 \mu \mathrm{L})$ and DNSH standard solution $(50 \mu \mathrm{L})$ were added to the wells before the plate was incubated for $1 \mathrm{~h}$ at $37^{\circ} \mathrm{C}$. After 3 washes with PBS with $0.05 \%$ Tween 20 , horseradish peroxidase-labeled goat antirabbit IgG solution $(100 \mu \mathrm{L})$ was added to each well and the plate was incubated for $20 \mathrm{~min}$ at $37{ }^{\circ} \mathrm{C}$. The plate was washed before $1 \%(\mathrm{w} / \mathrm{v})$ tetramethylbenzidine $(100 \mu \mathrm{L})$ was added. Finally, the plate was incubated for $10 \mathrm{~min}$ at $37{ }^{\circ} \mathrm{C}$ before $2 \mathrm{~mol} / \mathrm{L} \mathrm{H}_{2} \mathrm{SO}_{4}(50 \mu \mathrm{L})$ was added to stop the reaction. The plate was read at $450 \mathrm{~nm}$ using an ELISA plate reader.

Relative absorbance was calculated using the formula $\mathrm{B} / \mathrm{B}_{0}$, where $\mathrm{B}_{0}$ was the absorbance of the well without DNSH and B was the absorbance of the well with DNSH. The standard curves were constructed by plotting relative absorbance average values against the logarithm of DNSH concentrations with three replicates per concentration. Sigmoidal curves were fitted to four-parameter logistic equation and the standard deviations $(n=3)$ were calculated, using Origin Program 7.5 software packages.

The specificities of the ELISAs against several veterinary chemicals were determined and calculated as the cross reaction rate $(\mathrm{CR})$.

$$
\mathrm{CR}(\%)=\frac{\mathrm{IC}_{50(D N S H)}}{\mathrm{IC}_{50(\text { test compound })}} \times 100
$$

\section{Preparation of samples}

Chicken samples were purchased in a local retail outlet. The chicken was cut into small pieces. The tested samples were respectively spiked with methanol solutions $(10 \mu \mathrm{L})$ containing different DNSH concentrations $(0.1,0.2,0.8$ and $2.0 \mathrm{nmol} / \mathrm{g}$ chicken). A sample without DNSH was used as a negative 
control. The homogenized sample $(1.0 \mathrm{~g})$ was transferred into a glass tube and distilled water $(0.9 \mathrm{~mL})$ and $1 \mathrm{~mol} / \mathrm{L} \mathrm{HCl}(0.1 \mathrm{~mL})$ were added and mixed for $10 \mathrm{~min}$ using a vortex mixer. After centrifugation for $2 \mathrm{~min}$ at 10,000 rpm, the supernatant phase was collected. The supernatant was mixed with ether (1 $\mathrm{mL}$ ) for $60 \mathrm{~s}$ using a vortex mixer and then centrifuged for $2 \mathrm{~min}$ at 10,000 rpm. The water phase was collected after centrifugation. The DNSH content of the water phase was evaporated to dryness at 50 ${ }^{\circ} \mathrm{C}$ under nitrogen. Then, methanol $(2 \mathrm{~mL})$ was added, mixed for $10 \mathrm{~min}$ using a vortex mixer and centrifuged for $2 \mathrm{~min}$ at $10,000 \mathrm{rpm}$. Finally, the methanol phase was evaporated to dryness at $50{ }^{\circ} \mathrm{C}$ under nitrogen. The obtained residue was redissolved in $0.5 \mathrm{~mL}$ of assay buffer mentioned above and placed in an ultrasonic bath for $2 \mathrm{~min}$, followed by mixing for 2 min with a vortex. DNSH content was detected by the above-mentioned indirect ELISA method.

\section{Acknowledgements}

The work was supported by the Natural Science Foundation of Guangdong Province (06300421 and 06300423), the Headmaster's Science Fund of High Schools (5100-k06133) and Public Bidding Items Fund for a Great Breakthrough in Key Fields (2006A25005002) and the Research Fund for the Doctoral Program of Higher Education (20050564011).

\section{References and Notes}

1. Commission Decision No. 2002/657/EC.

2. Verdon, E.; Couedor, P.; Sanders, P. Multi-residue monitoring for the simultaneous determination of 5 nitrofurans (furazolidone, furaltadone, nitrofurazone, nitrofurantoin, nifursol) in poultry muscle tissue through the detection of their five major metabolites (AOZ, AMOZ, SEM, AHD, DNSAH) by liquid chromatography coupled to electrospray tandem mass spectrometry-In-house validation in line with Commission Decision 657/2002/EC. Anal. Chim. Acta 2007, 586, 336-347.

3. Vahl, M. Analysis of nifursol residues in turkey and chicken meat using liquid chromatographytandem mass spectrometry. Food Addit. Contam. 2005, 22, 120-127.

4. Mulder, P. P. J.; Zuidema, T.; Keestra, N. G. M.; Kooij, P. J. F.; Elbers, I. J. W.; van Rhijn, J. A. Determination of nifursol metabolites in poultry muscle and liver tissue. Development and validation of a confirmatory method. Analyst 2005, 130, 763-771.

5. Nunes, G. S.; Toscano, I. A.; Barcelo, D. Analysis of pesticides in food and environmental samples by enzyme-linked immunosorbent assays. Trends. Analyt. Chem. 1998, 17, 79-87.

6. Peterson, E. C.; Gunnell, M.; Che, Y. N.; Goforth, R. L.; Carroll, F. I.; Henry, R.; Liu, H. M.; Owens, S. M. Using hapten design to discover therapeutic monoclonal antibodies for treating methamphetamine abuse. J. Pharmacol. Exp. Ther. 2007, 322, 30-39.

7. Liu Y. H.; Jin M. J.; Gui W. J.; Cheng J. L.; Guo Y. R.; Zhu G. N. Hapten design and indirect competitive immunoassay for parathion determination: Correlation with molecular modeling and principal component analysis. Anal. Chim. Acta 2007, 591, 173-182.

8. Marvin H. G.; Bruce D. H. Hapten design for compound-selective antibodies: ELISAS for environmentally deleterious small molecules. Anal. Chim. Acta 1998, 376, 83-91. 
9. Shen, Y. D.; Wang, Y.; Zhang, S. W.; Xiao, Z. L.; Sun, Y. M.; Bu, X. Z.; Gu, L. Q. Design and efficient synthesis of novel haptens and complete antigens for the AOZ, a toxic metabolite of furazolidone. Chin. Chem. Lett. 2007, 18, 1490-1492.

10. Gupta, G. L. New synthesis of salicylhydrazide and its nitro derivatives. Curr. Sci. 1964, 33, 616-17.

11. White, R. L. Jr.; Wessels, F. L.; Schwan, T. J.; Ellis, K. O. 1-[[[5-(Substituted phenyl)-2oxazolyl]methylene]amino]-2,4-imidazolidinediones, a new class of skeletal muscle relaxants. $J$. Med. Chem. 1987, 30, 263-266.

12. El-Gendy, Z.; Morsy, J. M.; Allimony, H. A.; Abdel-Monem, W. R.; Abdel-Rahman, R. M. Synthesis of heterobicyclic nitrogen systems bearing the 1,2,4-triazine moiety as anti-HIV and anticancer drugs, part III. Pharmazie 2001, 56, 376-383.

13. Hong, X. Z.; Sun, M. Q. The Technology of Protein Linking. China Medical Technology Press: Beijing, P. R. China, 1993; pp. 2-56.

14. Sashidhar, R. B.; Capoor, A. K.; Ramana, D. Quantitation of $\varepsilon$-amino group using amino acids as reference standards by trinitrobenzenesulfonic acid. A simple spectrophotometric method for the estimation of hapten to carrier protein ratio. J. Immunol. Method 1994, 167, 121-127.

15. Zhang Q.; Wang L. B.; Ahn K. C.; Sun Q.; Hu B. S.; Wang J.; Liu F. Q. Hapten heterology for a specific and sensitive indirect enzyme-linked immunosorbent assay for organophosphorus insecticide fenthion. Anal. Chim. Acta 2007, 596, 303-311.

16. Wengatz I.; Stoutamire D.; Gee S. J.; Hammock, B. D. Development of an ELISA for the detection of the pyrethroid insecticide fenpropathrin, J. Agric. Food Chem. 1998, 46, 2211-2221.

Sample Availability: Available from the authors.

(C) 2008 by the authors; licensee Molecular Diversity Preservation International, Basel, Switzerland. This article is an open-access article distributed under the terms and conditions of the Creative Commons Attribution license (http://creativecommons.org/licenses/by/3.0/). 